\title{
Re-theorising mobility and the formation of culture and language among the Corded Ware Culture in Europe
}

Kristian Kristiansen ${ }^{1, *}$, Morten E. Allentoft ${ }^{2}$, Karin M. Frei ${ }^{3}$, Rune Iversen ${ }^{4}$, Niels N. Johannsen ${ }^{5}$, Guus Kroonen ${ }^{6}$, Łukasz Pospieszny ${ }^{7}$, T. Douglas Price ${ }^{8}$, Simon Rasmussen ${ }^{9}$, Karl-Göran Sjögren ${ }^{1}$, Martin Sikora ${ }^{2} \&$ Eske Willerslev $^{2,10,11}$

Recent genetic, isotopic and linguistic research has dramatically changed our understanding of how the Corded Ware Culture in Europe was formed. Here the authors explain it in terms of local adaptations and interactions between migrant Yamnaya people from the Pontic-Caspian steppe and indigenous North European Neolithic cultures. The original herding economy of the Yamnaya migrants gradually gave way to new practices of crop cultivation, which led to the adoption of new words for those crops. The result of this hybridisation process was the formation of a new material culture, the Corded Ware Culture, and of a new dialect, Proto-Germanic. Despite a degree of hostility between expanding Corded Ware groups and indigenous Neolithic groups, stable isotope data suggest that exogamy provided a mechanism facilitating their integration. This article should be read in conjunction with that by Heyd (2017, in this issue).

1 Department of Historical Studies, University of Gothenburg, SE Box 200, 40530 Gothenburg, Sweden

2 Centre for GeoGenetics, Natural History Museum of Denmark, University of Copenhagen, Øster Voldgade 5-7, 1350 Copenhagen K, Denmark

3 Environmental Archaeology and Materials Science, The National Museum of Denmark, I.C. Modewegsvej, Brede, 2800 Kongens Lyngby, Denmark

The Saxo Institute, University of Copenhagen, Karen Blixens Plads 8, 2300 Copenhagen S, Denmark

Department of Archaeology, Aarhus University, Moesgard Allé 20, 8270 Højbjerg, Denmark

6 Department of Nordic Studies and Linguistics, University of Copenhagen, Njalsgade 120, 2300 Copenhagen S, Denmark

Institute of Archaeology and Ethnology, Polish Academy of Sciences, ul. Rubiez 46, 61-612 Poznań, Poland

8 Department of Anthropology, University of Wisconsin-Madison, 1180 Observatory Drive, Madison, WI 53706, $U S A$

9 Department of Bio and Health Informatics, Technical University of Denmark, Kemitorvet 208, 2800 Kongens Lyngby, Denmark

10 Department of Zoology, University of Cambridge, Downing Street, Cambridge CB2 3EJ, UK

11 Wellcome Trust Sanger Institute, Wellcome Trust Genome Campus, Hinxton, Cambridge CB10 1SA, UK

Author for correspondence (Email: kristian.kristiansen@archaeology.gu.se)

(C) Antiquity Publications Ltd, 2017. This is an Open Access article, distributed under the terms of the Creative Commons Attribution licence (http://creativecommons.org/licenses/by/4.0/), which permits unrestricted reuse, distribution, and reproduction in any medium, provided the original work is properly cited.

ANTIQUITY 91356 (2017): 334-347

doi:10.15184/aqy.2017.17 


\section{Introduction}

With recent results from ancient DNA research showing an extensive incoming gene flow into Europe shortly after 3000 BC (Allentoft et al. 2015; Haak et al. 2015), we are finally in a position where migrations can be documented rather than debated as an element in the formation of the Corded Ware Culture. This has lifted an interpretative burden from archaeology in much the same way as $\operatorname{did}{ }^{14} \mathrm{C}$ dating when it was introduced. The new 'freedom' can instead be invested in properly theorising and interpreting local processes of migration, integration and consolidation, which represent an underdeveloped field of research. By integrating recent results from genetics, stable isotopes, archaeology and historical linguistics, this will in turn allow us to formulate better-founded models for the interaction of intruding and settled groups and the formation of a new material culture, and consequently better models for language dispersal and language change.

\section{Re-theorising migrations}

The evidence from the recent studies of ancient DNA documenting human migrations into temperate Europe during the early third millennium BC can be summarised as follows:

- There was a widespread process of genetic admixture, leading to a reduction of Neolithic DNA in temperate Europe and the dramatic increase of a new genomic component that was only marginally present in Central Europe prior to $3000 \mathrm{BC}$ (Allentoft et al. 2015; Haak et al. 2015; Cassidy et al. 2016).

- Although the details of this admixture event can and will be debated for years to come (Vander Linden 2016), it remains beyond question that the observed change in the gene pool must have involved the migration of people. Moreover, the apparent abruptness with which this change occurred suggests that it was a large-scale migration event, rather than a slow periodic gene flow across many centuries.

- The Yamnaya people from the Pontic-Caspian steppe are the best-known proxy for this incoming gene flow. The exact source could have been another, yet unsampled, group of people, but, in that case, they must have been very closely related genetically to Yamnaya.

What facilitated this major demographic event remains open to speculation, but the late fourth millennium BC was a period of widespread technological innovation, which also introduced long-distance travel. This horizon could thus have formed a prelude to the Yamnaya migrations, opening up new corridors of cultural transmission on which subsequent developments depended (Johannsen \& Laursen 2010; Hansen 2011, 2014). Moreover, a decline in Neolithic activity around 3000 BC (Hinz et al. 2012; Shennan et al. 2013) could indicate a crisis in Neolithic societies, thereby allowing space for incoming migrants. In that light, the recent documentation of an early form of plague, widespread from Siberia to the Baltic in the early third millennium BC, could play a key role in explaining this genetic changeover (Rasmussen et al. 2015).

These extensive demographic changes led to the formation of a new social and economic order in large parts of temperate Europe, resulting in the formation of the Corded Ware 
Culture. As evident from, for example, western Jutland (Andersen 1993; Kristiansen 2007), Corded Ware people burned down forests on a massive scale, thereby creating open, steppelike grazing lands for their herds. A more gradual opening of the landscape is also found in other regions (Doppler et al. 2015), while subsistence seems to have been a variable mix of cultivation, husbandry and some hunting and gathering (Müller et al. 2009).

The Corded Ware Culture elected the battle-axe as the most prominent male symbol, and created new types of pottery. Among the Yamnaya cultures, the tradition of potterymaking was weakly developed. Being a pastoral, mobile economy, they instead employed containers made of leather, wood and bast, and woven vessels could have been used as well, just as they used mats and other lightweight materials that were easy to transport in their wagons (Shishlina 2008: 60, fig. 54).

The Corded Ware Culture had widely shared similarities in burial rituals over vast distances (Furholt 2014: fig. 7), and had strong affinities to the Yamnaya burial rituals known from the steppe. The tens of thousands of small, single-grave barrows in Northern Europe were aligned in rows across the landscape, in a similar way to the practice on the steppe. They formed visible lines of communication in these vast open environments (Hübner 2005; Bourgeois 2013).

The unifying element between Yamnaya and Corded Ware is the burial ritual of a single inhumation under a barrow, even though there are minor differences in grave goods and the positioning of the body. Burial rituals are among the most fundamental social institutions in any society, as they relate to the transmission of property and power at death, to cosmology and religion, and, in the case of settlements, to the way households are organised. We can therefore formulate this as an axiom:

A strong relationship exists between burial ritual and social and religious institutions, because a burial is the institutionalised occasion for the transmission of property and power, and the renewal of social and economic ties (Oestigaard \& Goldhahn 2006). A radical change in burial rites therefore signals a similar change in beliefs and institutions. If such a change occurs rapidly without transition it signals a transformation of society, often under strong external influence, possibly a migration (to be supported also by settlement change and economic change). This does not rule out the effects of internal contradictions, which, however, often go hand in hand with external forces of change.

By contrast, the portable material culture is more readily prone to change, as it relates to various forms of personal identity and group identities that may fluctuate in time and space, as demonstrated by Hodder (1982). The institutions of burial ritual and of households or settlements should therefore form the core in comparative analyses of mobility and migrations because they do not change easily (see too Kristiansen 1989; Burmeister 2000; Prien 2005). Lack of a theoretical understanding of social institutions, and their differing role in organising material culture, goes a long way to explaining the many failed attempts to come to terms with migrations in the archaeological record, as well as with various forms of ethnicity (e.g. Andresen 2004; Brather 2004). Portable material culture can be used selectively to identify mobility, depending on its social and personal role. Thus, fibulae and pins are carried as part of dress, and may be helpful in defining the movements of (C) Antiquity Publications Ltd, 2017 
individuals. Most previous research on the Corded Ware Culture has used portable material culture, especially pottery, as a diagnostic feature, and therefore stressed differences between Corded Ware and Yamnaya steppe cultures while overlooking more basic similarities. We therefore need to re-analyse the (possible) social processes from initial Yamnaya migration to settling down and forming a new material culture: Corded Ware (Furholt 2014).

\section{The formation of the Yamnaya and Corded Ware Cultures}

Given that widespread migrations from the Caspian-Pontic steppe now constitute a key element in any plausible explanation of the Corded Ware phenomenon, we need to focus attention on how it unfolded locally in order to understand processes of demographic and cultural dominance. But we also need to understand the economic and social system of the Yamnaya culture from which it originated, and which flourished and expanded from around 3000 BC (Anthony 2007).

First, it should be noted that the Yamnaya cultures of the Pontic and Caspian steppe represented the first development of a fully pastoral economy that exploited different ecological niches during small-scale seasonal movements of people and animals between summer and winter grazing. Its economy and variability has been analysed in detail by Natalia Shishlina in a classic work (Shishlina 2008). This variability is also reflected in diet (Shishlina et al. 2012). The period after 3000 BC saw a more humid climate that favoured grassland productivity, and thus the new pastoral economy experienced a rapid demographic expansion that included eastern Central Europe: Bulgaria, Hungary and Transylvania, and Northern Europe soon afterwards (Harrison \& Heyd 2007; Heyd 2011; Gerling et al. 2012; Horváth et al. 2013; Kaiser \& Winger 2015). Herds consisted of cattle, sheep and horse, and the mobile lifestyle within small territories was supported by the use of wagons as mobile homes. Only a few stable settlements are known, but from burial pits, we find extensive use of thick plant mats and felt covers; the same materials were probably in use for dwellings. Light-framework dwellings could easily be assembled and disassembled and transported on pack animals. The economy was based on meat and dairy products, as well as fish (reflected in high ${ }^{15} \mathrm{~N}$ values), and seeds from wild plants were collected and used in soup with meat (Schulting \& Richards 2016). No agriculture is documented, but to the west, some cereal cultivation was practised (Pashkevych 2012). Extensive exchange systems linked different groups together and secured access to products outside the pastoral economy, such as metal. The healthy diet meant that life expectancy was fairly high, with many individuals living to 50-60 years old. We can also observe a selection for lactose tolerance and for height (Mathieson et al. 2015). Barrows were aligned in groups forming lines in the landscape to mark seasonal routes. Similar arrangements are found in Northern Europe, suggesting a shared perception and use of landscapes among Single Grave populations from Holland to western Jutland (Hübner 2005; Bourgeois 2013).

Secondly, we should observe that Corded Ware Cultures co-existed with late Neolithic cultures for shorter or longer periods across much of Central and Northern Europe. In Denmark, there were late Funnel Beaker communities in the Danish islands (Iversen 2015); in other parts of Northern Europe they were often in close proximity, such as the Globular Amphora Culture in Poland (Szmyt 1999). What we observe, therefore, in the 
archaeological record is a gradual process of acculturation and integration, which meant that after $2400 \mathrm{BC}$, the former strict cultural boundaries were gradually dissolved and a new, shared material culture appeared, represented first and foremost in Denmark by flint daggers, and in Central Europe by early Únetiče metal daggers. Bell Beaker groups had by now also emerged on the scene, introducing metallurgy, and they further complicated the mix of cultures and people. In burial rituals, however, old megalithic traditions still had an impact, as seen in a revival of stone cist burial in some regions. It was only on the advent of the Middle Bronze Age that cultural homogenisation prevailed. Thus, it took nearly 1000 years before all regions in Northern and Central Europe had adopted a shared social and cultural outlook that in all probability also included shared languages.

With the help of strontium isotopic analysis and ancient DNA we can now reconstruct in some detail the social processes behind the observable archaeological changes. At the Corded Ware cemetery of Eulau, the application of strontium isotopic tracing, ancient DNA and archaeology has allowed a full reconstruction of a singular family massacre and its local background (Haak et al. 2008; Meyer et al. 2009; Muhl et al. 2010). Four multiple burials contained single families of father, mother and children in various combinations, and it could be demonstrated that the mothers were of non-local origin, most probably originating in the Harz Mountains $50-60 \mathrm{~km}$ north of the settlement. The arrows that had killed the families confirmed this, as they belonged to another Neolithic culture: the Schönfeld, which was located in this area and practised cremation, a burial custom different to that of the Corded Ware Culture (compare Muhl et al. 2010: 44, 125). Contacts between the two are also illustrated by the occurrence of Schönfeld pottery in Corded Ware graves in the Halle-Saale region (Furholt 2003). Other Neolithic groups in the region, such as the Bernburg Culture, practised collective burials of multiple family groups, as demonstrated by genetics, again being distinctively different from the Corded Ware practice of individual burials (Meyer et al. 2012). We observe two things: that Corded Ware males practised exogamy, perhaps marriage by abduction, which provides a possible explanation for the killing. The question is: was this a unique case, or did it reflect a more widespread marriage practice, as suggested by Schönfeld pottery in Corded Ware burials?

In a recent work on diet and mobility among Corded Ware cemeteries from southern Germany (Sjögren et al. 2016), it was possible to demonstrate that exogamy was indeed a common practice among Corded Ware groups in this larger region (from a sample of 60). Most adult women (between 28 and 42 per cent) were of non-local origin and had a different diet during childhood. Such evidence fits well with recent genetic information documenting more-varied mtDNA haplogroups among Corded Ware females than among males (Lazaridis et al. 2014).

The female diet was more similar to previous Neolithic diets, while in Corded Ware as a whole there is a shift towards higher $\delta^{15} \mathrm{~N}$ values, suggestive of a shift in diet and/or in cultivation practices. There may be several different explanations for this shift, such as intense forms of cultivation, higher reliance on freshwater fish, or on animal versus vegetable protein, or a greater reliance on milk and milk products. The latter is supported by a widespread opening-up of landscapes in some regions for grazing animals (Andersen 1993, 1995; Doppler et al. 2015; Dietre et al. 2016). The analysis comprises 60 individuals and covers the period from the early Corded Ware to the mature and late Corded Ware; in (C) Antiquity Publications Ltd, 2017 
other words, from 2900/2800-2300 BC. Among the burials from the earliest, colonising phase at Tiefbrunn, we find a multiple burial of three individuals: one older male with a hammer-headed pin of steppe type, a young adult male and a female child, around four years old. mtDNA haplogroups were different for all three, indicating that they were not related on the maternal side (Allentoft et al. 2015). Sr isotope ratios suggest that the older man was non-local, while the younger man and the child may have been locals. The skulls of all three individuals exhibited signs of severe trauma and they had probably suffered violent deaths, which again demonstrates that the newcomers were not always welcomed peacefully. There is a similar early burial from the Kujawy region in Poland, of an elderly male of non-local origin, who also had a hammer-headed pin showing steppe influence (Pospieszny et al. 2015). Analysis of ancient DNA from the Tiefbrunn multiple burial showed a high percentage of Yamnaya steppe DNA. The larger, consolidated cemeteries from Bergrheinfeld and Lauda-Königshofen are from the middle phase of the Corded Ware Culture (2600-2500 BC), and here the practice of exogamy was well established over a longer period of time. We cannot know where the non-local women were from, but as their diet looked more 'Neolithic', we may assume that they originated in late Neolithic cultures still residing on the higher elevations in the region.

Exogamy is a clever, and perhaps necessary, policy if new migrating groups are mainly constituted by males. This is a probable scenario for an expanding pastoral economy, and is supported by archaeological data from the early horizon of the Single Grave/Corded Ware Culture in Jutland, where 90 per cent of all burials belonged to males (Hübner 2005: 63233, fig. 454). It gains further support from later historical sources from India to the Baltic and Ireland (Falk 1986; Kershaw 2000). They describe, as a typical feature of these societies, the formation of warrior youth bands consisting of boys from 12-13 up to 18-19 years of age, when they were ready to enter the ranks of fully grown warriors. Such youthful warbands were led by a senior male, and they were often named 'Black Youth' or given names of dogs and wolves as part of their initiation rituals. The nature of this institution was recently summarised as follows:

In the Indo-European past, the boys first moved into the category of the (armed) youths and then, as members of the war-band of unmarried and landless young men, engaged in predatory wolf-like behaviour on the edges of ordinary society, living off hunting and raiding with their older trainers/models. Then about the age of twenty they entered into the tribe proper as adults (Petrosyan 2011: 345).

The activities of the young war-bands were seasonal; during the rest of the year they lived within their households and communities, perhaps engaged in herding animals and other forms of farm labour. Such bands were mainly made up of younger sons, as inheritance was restricted to the oldest son. Thus, they formed a dynamic force that could be employed in pioneer migrations (Sergent 2003). Archaeological evidence of this institution has been documented in the Russian steppe from the Bronze Age onwards (Pike-Tay \& Anthony 2016; Brown \& Anthony in press).

There is additional evidence to support the idea that males dominated the initial Yamnaya migrations and the formation of the early Corded Ware Culture: in burials from the earliest horizon, often with males, as in Tiefbrunn and Kujawy, there was no typical 
Corded Ware material culture. This was followed shortly afterwards by the deposit of Atype battle-axes in male burials, but there was as yet no pottery (Furholt 2014: 6, fig. 3). Corded Ware pottery appeared later in Northern Europe, and we may suggest that this did not happen until women with ceramic skills married into this culture and started to copy wooden, leather and woven containers in clay. This process began in the early phase both south and north of the Carpathians (Ivanova 2013; Frînculeasa et al. 2015).

Some confirmation of such material transformations is found in a uniquely preserved find of the typical flat bowl with short feet made of wood (Muhl et al. 2010: 47), well suited for turning milk into yogurt or similar dairy products overnight. Its pottery version became a shared type throughout the Corded Ware Culture, and later the Bell Beaker Culture.

We may also note that pastoral economies historically tend to dominate agrarian economies, as they are both more mobile and more warlike in their behaviour. Such a pattern of economic and social dominance, reflected in taking wives from farming cultures while sending young males in organised war-bands to settle in new territories, would explain both the genetic and linguistic dominance of the Yamnaya steppe migrations, the results of which we can observe to this day. Figure 1 summarises these transformative processes in a model.

\section{Language dispersal and the formation of Proto-Germanic in northern Europe}

These local processes of social integration between intruding Yamnaya/Corded Ware populations and remnant Neolithic populations can be applied to language dispersal. We should expect that the transformation from Proto-Indo-European to Pre-Proto Germanic would reveal the same kind of hybridisation between an earlier Neolithic language of the Funnel Beaker Culture, and the incoming Proto-Indo-European language. This is precisely what recent linguistic research has been able to demonstrate (Kroonen \& Iversen in press). In their study on the formation of Proto-Germanic in Northern Europe, Kroonen and Iversen document a bundle of linguistic terms of non-Indo-European origin linked to agriculture that were adopted by Indo-European-speaking groups who were not fully fledged farmers. The most plausible, and perhaps the only possible, context for this to have happened would be the introduction of Proto-Germanic by the intruding Yamnaya groups. Archaeologically, this adoption can be understood from their interaction over several hundred years with late Funnel Beaker groups still residing in eastern Jutland and on the Danish islands, where they maintained a largely agricultural economy. From this we can conclude that terms linked to farming, and the cultivation of many important crops, were missing among the early Yamnaya/Corded Ware groups, who may well have acquired cereals (barley) mainly for the purpose of producing and consuming beer (Klassen 2005). In addition, we learn that the Neolithic language of the Funnel Beaker Culture was in all probability non-Indo-European. This process of language interaction is illustrated by the model in Figure 2. It illustrates that different Indo-European language branches were in contact with one and the same Neolithic tongue throughout Europe.

The new data conforms well to the reconstructed lexicon of Proto-Indo-European (Mallory \& Adams 2006), which provides important clues that the subsistence strategy (C) Antiquity Publications Ltd, 2017 

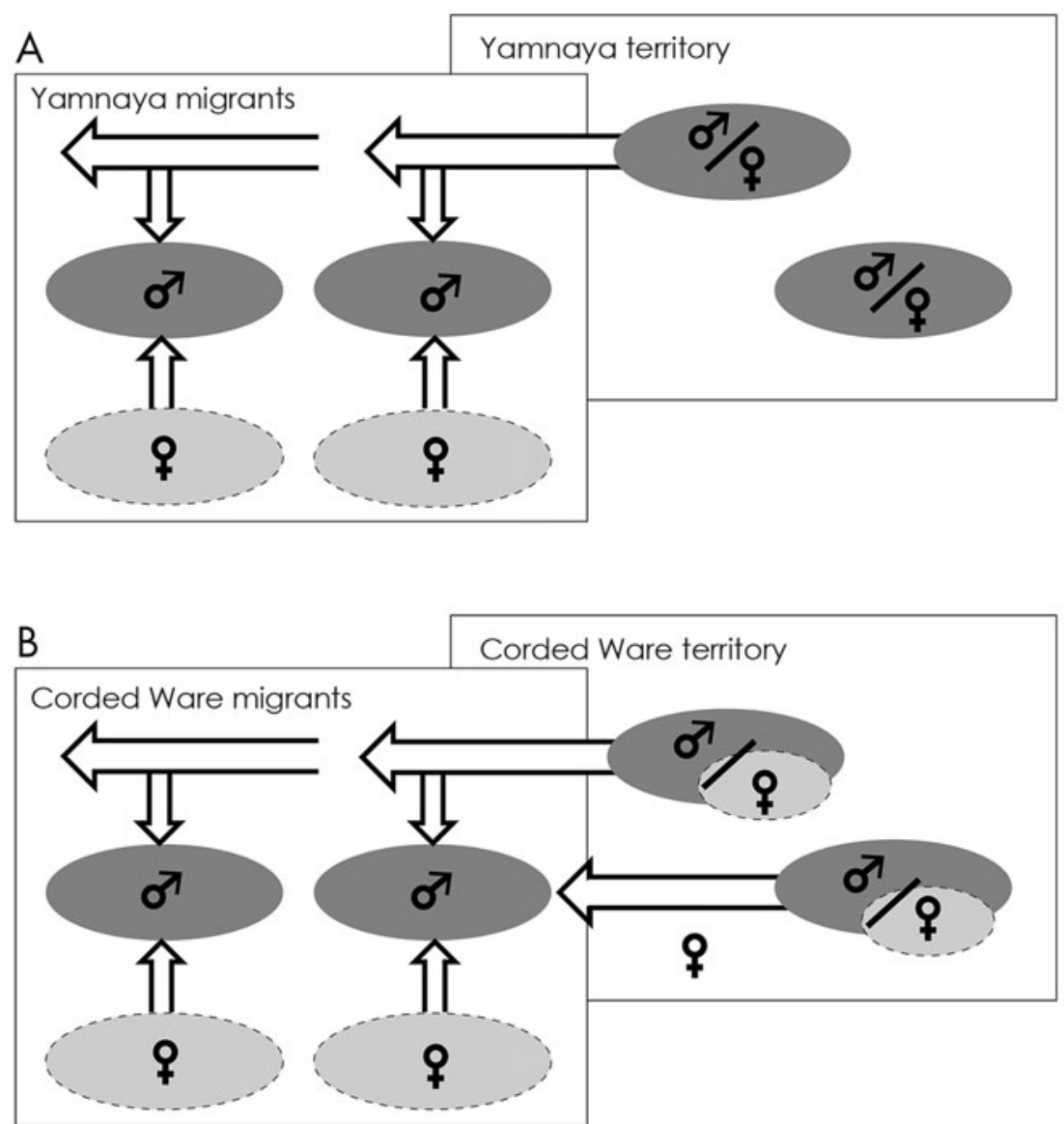

Figure 1. Model of the social processes of exogamy transforming Yamnaya to Corded Ware Culture, and its subsequent migration as Corded Ware Culture leading to further adaptations and transformations.

of early Indo-European-speaking societies was based on animal husbandry. It includes, for instance, terms related to dairy and wool production, horse breeding and wagon technology. Words for crops and land cultivation, however, have proved to be far more difficult to reconstruct. These results from historical linguistics are supported by similar evidence from archaeology (Andersen 1995; Kristiansen 2007). With the recent study by Kroonen and Iversen (in press), we can now demonstrate how social and economic interaction with existing Neolithic societies also had a corresponding linguistic imprint. This should not surprise us, as similar results are well documented from the interaction of Yamnaya societies with their northern Uralic-speaking neighbours (Parpola \& Koskallio 2007).

From this we may conclude that Funnel Beaker societies spoke a non-IndoEuropean language, and thus another pillar in support of the Anatolian hypothesis of farming/language dispersal (Renfrew 1987) has fallen. When the whole complex of wagon terminology is taken into account, i.e. 'wheel', 'axle', 'nave', 'thill', 'yoke', 'hame' (Anthony \& Ringe 2015: tab. 1, fig. 1), the idea that all of those terms arose independently in the daughter languages seems extremely unlikely. When we add the evidence from ancient 


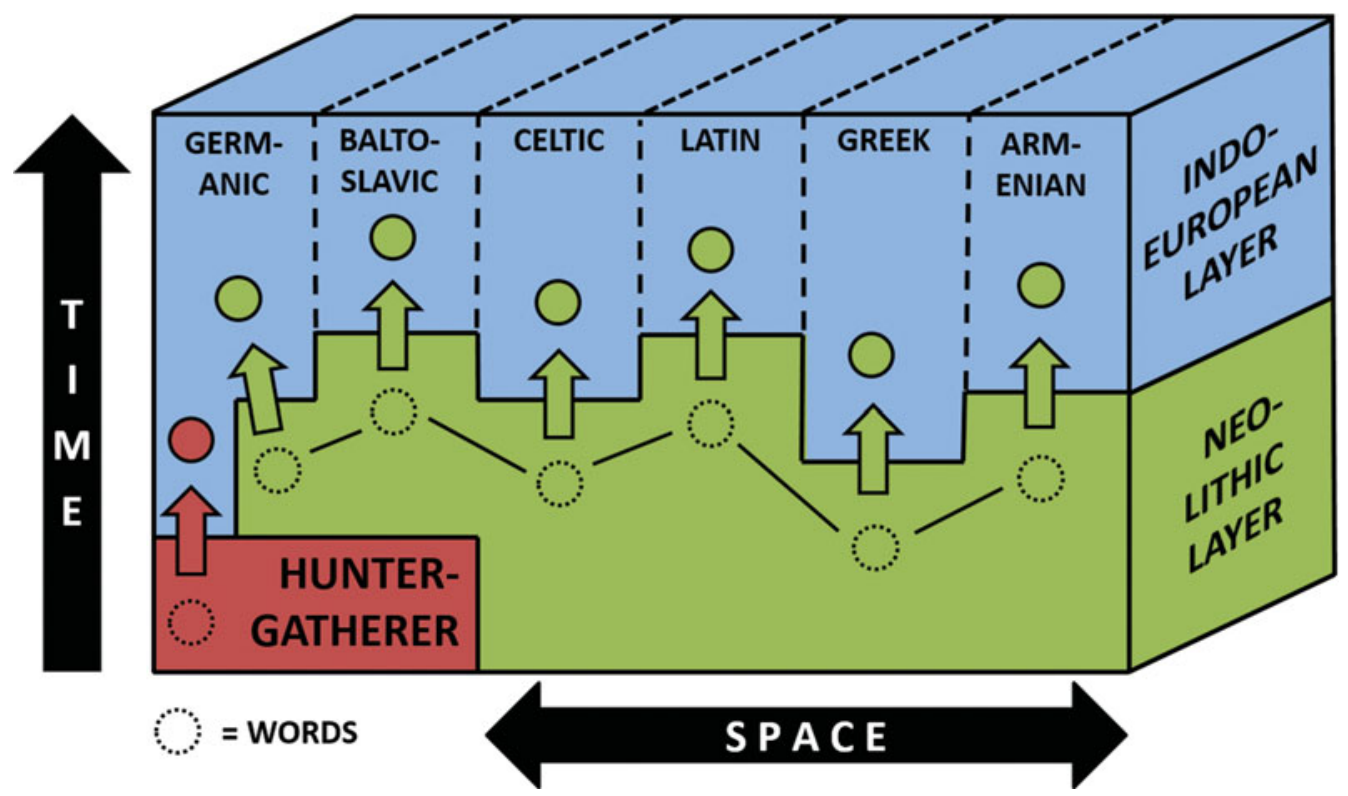

Figure 2. Schematic representation of how different Indo-European branches have absorbed words (circles) from a lost Neolithic language or language group (dark fill) in the reconstructed European linguistic setting of the third millennium $B C$, possibly involving one or more hunter-gatherer languages (light fill) (after Kroonen \& Iversen in press).

DNA, and the additional evidence from recent linguistic work discussed above, the Anatolian hypothesis must be considered largely falsified. Those Indo-European languages that later came to dominate in western Eurasia were those originating in the migrations from the Russian steppe during the third millennium BC.

\section{Conclusion}

We have been able to reconstruct the social processes of cultural integration and hybridisation that followed from (probable) Neolithic women marrying into Yamnaya settlements dominated by males of first-generation migrants. This practice continued over several generations, and the women soon started to produce new pottery versions of existing containers made of organic materials, with some further innovations. The original herding economy of the Yamnaya migrants gradually gave way to new agrarian practices of crop cultivation, which led to the adaptation of new words. The result of this hybridisation process was the formation of a new material culture, the Corded Ware Culture, and of a new dialect, Proto-Germanic (or perhaps more correctly, Pre-Proto-Germanic). The latter was likewise an adaptation to new conditions, with the borrowing of novel terms from neighbouring Neolithic communities and from women who had married in to the migrant communities. Archaeology here provides a socio-linguistic setting for a process of language change over several hundred years between 2800 and 2400 BC.

This integrated model of cultural, linguistic and genetic change explains the formation of Corded Ware Cultures as a result of local adaptations and of interaction between migrant Yamnaya populations and indigenous Neolithic cultures. The social institution of (C) Antiquity Publications Ltd, 2017 
exogamy provided an integrating mechanism, despite sometimes hostile relations between intruding Corded Ware groups and residing Neolithic groups; the burials at Eulau are the most prominent example of this. Burial rituals also reveal a major difference in property relations and thus social organisation between existing Neolithic groups and intruding Yamnaya/Corded Ware groups. Both Yamnaya and Corded Ware groups shared individual burials under small family mounds, reflecting the transmission among individual families of animals and other property between generations. In contrast to this, the collective, megalithic or similar type burials of Neolithic groups reflected collective, clan-like shared ownership of property, animals and land. This collision of ideologies was played out gradually, with the Corded Ware political economy and interlinked cosmology as the winner once we enter the Bronze Age. Some influences from the Neolithic past, however, remained in both language and social organisation. This new historical interpretation rests on relatively solid ground, and represents a return to a more dramatic past than the prevailing model of cultural and technological transmissions. Some may not like it for its resemblance to an older paradigm of migrations as a primary cause of cultural change, as represented by Gustav Kossinna and Gordon Childe (Kristiansen 1998: 7-24), but we are now in a position to unravel the complexities behind the historical processes in much detail, and thus avoid the simplistic models of the past. Through this we realise that peaceful interaction and intermarriage between culturally and genetically different groups formed the day-to-day foundations of social life, interspersed with episodes of conflict. In the long term, however, the Corded Ware social formation had the potential to dominate, not least when supported by the migrations of related Bell Beaker groups. Together, their social and demographic force would finally create the foundations for the rise of the Bronze Age. We are only beginning to understand these processes, however, and much new evidence can be expected that will add detail and refine our models, while retaining the big picture.

\section{Acknowledgements}

Research for this paper was part of the project 'Travels, transmissions and transformations in the $3^{\text {rd }}$ and $2^{\text {nd }}$ millennium BC in northern Europe: the rise of Bronze Age societies' at the University of Gothenburg, led by Kristian Kristiansen and funded by the European Research Council (ERC Advanced Grant ERC-2010-AdGProposal $n^{\circ} 269442$ THE RISE). It also produced the genetic and isotopic research behind the following articles: Allentoft et al. 2015; Pospieszny et al. 2015; Rasmussen et al. 2015; Sjögren et al. 2016.

\section{References}

Allentoft, M.E., M. Sikora, K.-G. Sjögren, S. Rasmussen, M. Rasmussen, J. Stenderup, P.B. Damgaard, H. Schroeder, T. Ahlström, L. Vinner, A.-S. Malaspinas, A. Margaryan, T. Higham, D. Chivall, N. Lynnerup,

L. Harvig, J. Baron, P. Della Casa, P. Dąbrowski, P.R. Duffy, A.V. Ebel,

A. Epimakhov, K. Frei, M. Furmanek,

T. Gralak, A. Gromov, S. Gronkiewicz,

G. Grupe, T. Hajdu, R. Jarysz,

V. Khartanovich, A. Khokhlov, V. Kiss,

J. KoláŘ, A. Krisska, I. Lasak, C. Longhi,

G. McGlynn, A. Merkevicius, I. Merkyte,
M. Metspalu, R. Mkrtchyan, V. Moiseyev, L. Paja, G. Pálfi, D. Pokutta, Ł. Pospieszny, T.D. Price, L. SaAg, M. Sablin, N. Shishlina, V. Smrčka, V.I. Soenov, V. Szeverényi, G. Tóth, S.V. Trifanova, L. Varul, M. Vicze,

L. Yepiskoposyan, V. Zhitenev, L. Orlando, T. Sicheritz-Pontén, S. Brunak, R. Nielsen, K. Kristiansen \& E. Willerslev. 2015.

Population genomics of Bronze Age Eurasia. Nature 522: 167-72.

https://doi/.org/10.1038/nature14507

Andersen, S.T. 1993. History of vegetation and agriculture at Hassing Huse Mose, Thy, northwest Denmark, since the Ice Age. Journal of Danish Archaeology 11: 57-79. 
- 1995. Pollen analytical investigations of barrows from the Funnel Beaker and Single Grave Cultures in the Vroue area, west Jutland, Denmark. Journal of Danish Archaeology 12: 107-31.

ANDresen, M. 2004. Studien zur Geschichte und Methodik der archäologischen Migrationsforschung. Münster, New York, München \& Berlin: Waxman.

Anthony, D. 2007. The horse, the wheel and language. How Bronze-Age riders from the Eurasian steppes shaped the modern world. Princeton (NJ): Princeton University Press.

Anthony, D.W. \& D. Ringe. 2015. The Indo-European homeland from linguistic and archaeological perspectives. Annual Review of Linguistics 2015(1): 199-219. https://doi.org/ 10.1146/annurev-linguist-030514-124812

Bourgeois, Q. 2013. Monuments on the horizon: the formation of the barrow landscape throughout the $3^{\text {rd }}$ and the $2^{\text {nd }}$ millennium BC. Leiden: Sidestone.

Brather, S. 2004. Ethnische Interpretationen in der frühgeschichtlichen Archäologie. Berlin \& New York: De Gruyter. https://doi.org/ $10.1515 / 9783110922240$

Brown, D.R. \& D.W. Anthony. In press. Midwinter dog sacrifices and warrior initiations in the Russian steppes at Krasnosamarskoe.

Burmeister, S. 2000. Archaeology and migration: approaches to an archaeological proof of migration. Current Anthropology 41: 539-67. https://doi.org/10.1086/317383

Cassidy, L.M., R. Martiniano, E.M. Murphy, M.D. Teasdale, J. Mallory, B. Hartwell \& D.G. Bradley. 2016. Neolithic and Bronze Age migration to Ireland and establishment of the insular Atlantic genome. Proceedings of the National Academy of Sciences of the USA 113: 368-73. https://doi.org/ 10.1073/pnas.1518445113

Dietre, B., C. Walser, W. Kofler, K. Kothieringer, I. Hajdas, K. Lambers, T. Reitmaier \& N. HaAs. 2016. Neolithic to Bronze Age (4850-3450 BP) fire management of the Alpine Lower Engadine landscape (Switzerland) to establish pastures and cereal fields. The Holocene. Published online 8 August 2016. https://doi.org/ $10.1177 / 0959683616658523$

Doppler, T., C. Gerling, V. Heyd, C. Knipper, T. Kuhn, M.F. Lehmann, A.W.G. Pike \& J. SChibler. 2015. Landscape opening and herding strategies: carbon isotope analyses of herbivore bone collagen from the Neolithic and Bronze Age lakeshore site of Zürich-Mozartstrasse, Switzerland. Quaternary International. Published online 1 October 2015.

https://doi.org/10.1016/j.quaint.2015.09.007

FALK, H. 1986. Bruderschaft und Würfelspiel. Untersuchungen zur Entwicklungsgeschichte des vedischen Opfers. Freiburg: Hedwig Falk.
Frînculeasa, A., B. Preda \& V. Heyd. 2015. Pit-graves, Yamnaya and Kurgans along the Lower Danube. Praehistorische Zeitschrift 90: 45-113. https://doi.org/10.1515/pz-2015-0002

Furholt, M. 2003. Die absolutchronologische Datierung der Schnurkeramik in Mitteleuropa und

Sü̈skandinavien (Universitaätsforschungen zur Prähistroschen Archäologie 101). Bonn: Habelt. https://doi.org/10.1017/ppr.2013.20

- 2014. Upending a 'totality': re-evaluating Corded Ware variability in Late Neolithic Europe. Proceedings of the Prehistoric Society 80: 67-86.

Gerling, C., E. BÁnffy, J. Dani \& K. Köhler. 2012. Immigration and transhumance in the Early Bronze Age Carpathian Basin: the occupants of a kurgan. Antiquity 86: 1097-111. https://doi.org/10.1017/S0003598X00048274

HaAk, W., G. Brandt, H.N. de Jong, C. Meyer, R. Ganslmeier, V. Heyd, C. Hawkesworth, A.W.G. Pike, H. Meller \& K.W. Alt. 2008. Ancient DNA, strontium isotopes and osteological analyses shed light on social and kinship organization of the Later Stone Age. Proceedings of the National Academy of Sciences of the USA 105: 18226-31. https://dx.doi.org/10.1073/pnas.0807592105

HaAk, W., I. Lazaridis, N. Patterson, N. Rohland, S. Mallick, B. Llamas, G. Brandt, S. Nordenfelt, E. Harney, K. Stewardson, Q. Fu, A. Mittinik, E. Bánffy, C. Economou, M. Francken, S. Friederich, R. Garrido Pena, F. Hallgren, V. Khartanovich, A. Khokhlov, M. Kunst, P. Kuznetsov, H. Meller, O. Mochalov, V. Moiseyev, N. Nicklisch, S.L. Pichler, R. Risch, M.A. Rojo Guerra, C. Roth, A. SzÉCsÉnYi-Nagy, J. Wahl, M. Meyer, J. Krause, D. Brown, D. Anthony, A. Cooper, K.W. Alt \& D. Reich. 2015. Massive migration from the steppe was a source for Indo-European languages in Europe. Nature 522: 207-11. https://doi.org/10.1038/nature14317

Hansen, S. 2011. Technische und soziale Innovationen in der zweiten hälfte des 4. Jahrtausend v. Chr., in S. Hansen \& J. Müller (ed.) Sozialarchäologische Persepktiven: Gesellschaftlicher Wandel 5000-1500v. Chr. Zwischen Atlantik und Kaukasus: 153-91. Berlin: Phillipp von Zabern.

- 2014. The $4^{\text {th }}$ millennium: a watershed in European prehistory, in B. Horejs \& M. Mehofer (ed.) Western Anatolia before Troy. Proto-urbanisation in the $4^{\text {th }}$ millennium BC? Proceedings of the International Symposium held at the Kunsthistorisches Museum Wien, Vienna, Austria, 21-24 November, 2012: 243-60. Vienna: Austrian Academy of Sciences.

(C) Antiquity Publications Ltd, 2017 


\section{Re-theorising mobility and the formation of culture and language}

Harrison, R. \& V. Heyd. 2007. The transformation of Europe in the third millennium BC: the example of 'Le Petit Chasseur I + III' (Sion, Valais, Switzerland). Praehistorische Zeitschrift 82: 129-214. https://doi.org/10.1515/PZ.2007.010

Heyd, V. 2011. Yamnaya groups and tumuli west of the Black Sea, in S. Müller Celka \& E. Borgna (ed.) Ancestral landscapes: burial mounds in the Copper and Bronze Ages: 535-55. Lyon: Maison de l'Orient et de la Mediterranée.

- 2017. Kossinna's smile. Antiquity 91: 348-59.

Hinz, M., I. Feeser, K.-G. SJögren \& J. Müller. 2012. Demography and the intensity of cultural activities: an evaluation of Funnel Beaker Societies (4200-2800 cal BC). Journal of Archaeological Science 39: 3331-40. https://doi.org/10.1016/j.jas.2012.05.028

HodDer, I. 1982. Symbols in action: ethnoarchaeological studies of material culture. Cambridge: Cambridge University Press.

Horváth, T., J. Dani, Á. Pető, Ł. Pospieszny \& É.S. Svingor. 2013. Multidisciplinary contributions to the study of Pit Grave culture kurgans of the Great Hungarian Plain, in V. Heyd, G. Kulcsár \& V. Szeverényi (ed.) Transition to the Bronze Age: interregional interaction and socio-cultural change at the beginning of the third millennium BC in the Carpathian Basin and surrounding regions: 153-79. Budapest: Archaeolingua.

HüBNER, E. 2005. Jungneolithische Gräber auf der Jütischen Halbinsel. Typologische und chronologische Studien zur Einzelgrabkultur (Nordiske Fortidsminder, Serie B 24). København: Det Kgl. Nordiske Oldskriftselskab.

Ivanova, S. 2013. Connections between the Budzhak culture and Central European groups of the Corded Ware Culture. Baltic-Pontic Studies 18: 86-121.

IVERSEN, R. 2015. The transformation of Neolithic societies - an eastern Danish perspective on the $3^{\text {rd }}$ millennium $B C$ (Jutland Archaeological Society Publications 88). Højbjerg: Jutland Archaeological Society.

Johannsen, N. \& S. Laursen. 2010. Routes and wheeled transport in late $4^{\text {th }}$ - to early $3^{\text {rd }}$-millennium funerary customs of the Jutland Peninsula: regional evidence and European context. Praehistorische Zeitschrift 88: 15-58. https://doi.org/10.1515/pz.2010.004

Kaiser, E. \& K. Winger. 2015. Pit graves in Bulgaria and the Yamnaya culture. Praehistorische Zeitschrift 90: 114-40. https://doi.org/10.1515/pz-2015-0001

Kershaw, K. 2000. The one-eyed god: Odin and the (Indo-) Germanic Männerbund (Journal of Indo-European Studies monographs 36). Washington, D.C.: Institute for the Study of Man.
KLAssen, L. 2005. Refshøjgård. Et bemærkelsesværdigt gravfund fra enkeltgravskulturen. Kuml 2005: 17-59.

Kristiansen, K. 1989. Prehistoric migrations-the case of the Single Grave and Corded Ware cultures. Journal of Danish Archaeology 8: 211-25.

- 1998. Europe before history. Cambridge: Cambridge University Press.

- 2007. Eurasian transformations: mobility, ecological change and the transmission of social institutions in the third millennium and early second millennium BCE, in A. Hornborg \& C.E. Crumley (ed.) The world system and the Earth system: global socioenvironmental change and sustainability since the Neolithic: 149-62. Walnut Creek (CA): Left Coast.

Kroonen, G. \& R. Iversen. In press. Talking Neolithic: linguistic and archaeological perspectives on how Indo-European was implemented in southern Scandinavia. American Journal of Archaeology.

Lazaridis, I., N. Patterson, A. Mittnik, G. Renaud, S. Mallick, K. Kirsanow, P.H. Sudmant, J.G. Schraiber, S. Castellano, M. Lipson, B. Berger, C. Economou, R. Bollongino, Q. Fu, K.I. Bos, S. Nordenfelt, H. Li, C. De Filippo, K. Prüfer, S. Sawyer, C. Posth, W. HaAk, F. Hallgren, E. Fornander, N. Rohland, D. Delsate, M. Francken, J.-M. Guinet, J. Wahl, G. Ayodo, H.A. Babiker, G. Bailliet, E. Balanovska, O. Balanovsky, R. Barrantes, G. Bedoya, H. Ben-Ami, J. Bene, F. Berrada, C.M. Bravi, F. Brisighelli, G.B.J. Busby, F. Cali, M. Churnosov, D.E.C. Cole, D. Corach, L. Damba, G. Van Driem, S. Dryomov, J.-M. Dugoujon, S.A. Fedorova, I. Gallego Romero, M. Gubina, M. Hammer, B.M. Henn, T. Hervig,

U. Hodoglugil, A.R. Jha,

S. KarachanaK-Yankova, R. Khusainova, E. Khusnutdinova, R. Kittles, T. Kivisild, W. Klitz, V. Kučinskas, A. Kushniarevich, L. Laredj, S. Litvinov, T. Loukidis, R.W. Mahley, B. Melegh, E. Metspalu, J. Molina, J. Mountain, K. NÄKKäLÄJÄrvi, D. Nesheva, T. Nyambo, L. Osipova, J. Parik, F. Platonov, O. Posukh, V. Romano, F. RothHammer, I. Rudan, R. Ruizbakiev, H. Sahakyan, A. Sajantila, A. Salas, E.B. Starikovskaya, A. Tarekegn, D. Toncheva, S. Turdikulova, I. Uktveryte, O. Utevska, R. Vasquez, M. Villena, M. Voevoda, C.A. Winkler, L. Yepiskoposyan, P. Zalloua, T. Zemunik, A. Cooper, C. Capelli, M.G. Thomas, A. Ruiz-Linares, S.A. Tishkoff, L. Singh, K. Thangaraj, R. Villems, D. Comas, R. Sukernik, M. Metspalu, M. Meyer, E.E. Eichler, J. Burger, M. Slatkin, S. PäÄbo, J. Kelso, D. Reich \& J. Krause. 2014. Ancient 
human genomes suggest three ancestral populations for present-day Europeans. Nature 513: 409-13. https://doi.org/10.1038/nature13673

Mallory, J.P. \& D.Q. Adams. 2006. The Oxford introduction to Proto-Indo-European and the Proto-Indo-European world. Oxford: Oxford University Press.

Mathieson, I., I. Lazaridis, N. Rohland, S. Mallick, N. Patterson, S. Alpaslan Roodenberg, E. Harney, K. Stewardson, D. Fernandes, M. Novak, K. Sirak, C. Gamba, E.R. Jones, B. Llamas, S. Dryomov, J. Pickrell, J.L. Arsuaga, J.M. Bermúdez De Castro, E. Carbonell, F. Gerritsen, A. Khokhlov, P. Kuznetsov, M. Lozano, H. Meller, O. Mochalov, V. Moiseyev, M.A. Rojo Guerra, J. Roodenberg, J.M. Vergès, J. Krause, A. Cooper, K.W. Alt, D. Brown, D. Anthony, C. Lalueza-Fox, W. Haak, R. Pinhasi \& D. ReICH. 2015. Genome-wide patterns of selection in 230 ancient Eurasians. Nature 528: 499-503. https://doi.org/10.1038/nature16152

Meyer, C., G. Brandt, W. Haak, R.A.Ganslmeier, H. Meller \& K. Alt. 2009. The Eulau eulogy: bioarchaeological interpretation of lethal violence in Corded Ware multiple burials from Saxony-Anhalt, Germany. Journal of Anthropological Archaeology 28: 412-23. https://doi:10.1016/j.jaa.2009.07.002

Meyer, C., R. Ganslmeier, V. Dresely \& K.W. Alt. 2012. New approaches to the reconstruction of kinship and social structure based on bioarchaeological analysis of Neolithic multiple and collective graves, in J. Kolár \& F. Trampota (ed.) Theoretical and methodological considerations in Central European Neolithic archaeology (British Archaeological Reports international series 2325): 11-23. Oxford: Archaeopress.

Muhl, A., H. Meller \& K. Heckenhahn. 2010. Tatort Eulau. Ein 4500 Jahre altes Verbrechen wird Aufgeklärt. Stuttgart: Theiss.

Müller, J., T. Seregély, C. Becker \& A.-M. Christensen. 2009. A revision of Corded Ware settlement pattern-new results from the Central European low mountain range. Proceedings of the Prehistoric Society 75: 125-42. https://doi.org/10.1017/S0079497X00000323

Oestigandd, T. \& J. Goldhahn. 2006. From the dead and the living: death as transaction and re-negotiations. Norwegian Archaeological Review 39: 27-48. https://doi.org/10.1080/00293650600703928

Parpola, A. \& P. Koskallio (ed.). 2007. Early contacts between Uralic and Indo-European: linguistic and archaeological considerations (Mémoires de la Société Finno-Ougrienne 242). Helsinki: Finno-Ugrian Society.
Pashoevych, G. 2012. Environment and economic activities of Neolithic and Bronze Age populations of the northern Pontic area. Quaternary International 261: 176-82. https://doi.org/10.1016/j.quaint.2011.01.024

Petrosyan, A. 2011. Armenian traditional Black Youths: the earliest sources. Journal of Indo-European Studies 39: 342-53.

Pike-Tay, A. \& D.W. Anthony. 2016. Dog days of winter: seasonal activities in a Srubnaya landscape, in D.W. Anthony, D.R. Brown, A.A. Khokhlov, P.F. Kuznetsov \& O.D. Mochalow (ed.) A Bronze Age landscape in the Russian steppes. The Samara Valley Project: 373-85. Los Angeles (CA): Cotsen Institute of Archaeology.

Pospieszny, Ł., I. Sobkowiak-Tabaka, T.D. Price, K.M. Frei, I. Hildebrandt-Radke, H. Kowalewska-Marszalek, M. KrenZ-NiedbaŁa, M. Osypińska, M. Stró́żyK \& M. WiniaRSKA-KabaCiŃSKa. 2015. Remains of a late Neolithic barrow at Kruszyn. A glimpse of ritual and everyday life in early Corded Ware societies of the Polish lowland. Praehistorische Zeitschrift 90: 185-213. https://doi.org/10.1515/pz-2015-0009

Prien, R. 2005. Archäologie und Migration. Vergleichende Studien zur archäologischen Nachweisbarkeit von Wanderungsbewegungen (Universitätsforschungen zur Prähistorischen Archäologie 120). Bonn: Habelt.

Rasmussen, S., M.E. Allentoft, K. Nielsen, L. Orlando, M. Sikora, K.-G. SJögren, A.G. Pedersen, M. Schubert, A. Van Dam, C.M.O. Kapel, H.B. Nielsen, S. Brunak, P. Avetisyan, A. Epimakhov, M.V. Khalyapin, A. Gnuni, A. Kriiska, I. Lasak, M. Metspalu, V. Moiseyev, A. Gromov, D. Pokutta, L. SaAg, L. VARUL, L. YePISKOPOSYAN, T. Sicheritz-Pontén, R.A. Foley, M. Mirazón Lahr, R. Nielsen, K. Kristiansen \& E. WILLERSLEV. 2015. Early divergent strains of Yersinia pestis in Eurasia 5000 years ago. Cell 163: 571-82. https://doi.org/ 10.1016/j.cell.2015.10.009

Renfrew, C. 1987. Archaeology and language: the puzzle of Indo-European origins. London: Jonathan Cape.

Schulting, R.J. \& M.P. Richards. 2016. Stable isotope analysis of Neolithic to Late Bronze Age populations in the Samara Valley, in D.W. Anthony, D.R. Brown, A.A. Khokhlov, P.F. Kuznetsov \& O.D. Mochalov (ed.) A Bronze Age landscape in the Russian steppes. The Samara Valley Project: 127-49. Los Angeles (CA): Cotsen Institute of Archaeology.

Sergent, B. 2003. Les troupes de jeunes hommes et l'expansion indo-europenne. Dialogues d'histoire ancienne 29: 9-27.

(C) Antiquity Publications Ltd, 2017 
Shennan, S., S.S. Downey, A. Timpson,

K. Edinborough, S. Colledge, T. Kerig,

K. Manning \& M.G. Thomas. 2013. Regional population collapse followed initial agriculture booms in mid-Holocene Europe. Nature

Communications 4: article no. 2486.

https://doi.org/10.1038/ncomms3486

Shishlina, N. 2008. Reconstruction of the Bronze Age of the Caspian steppes: life styles and lifeways of pastoral nomads (British Archaeological Reports international series 1876). Oxford: Archaeopress.

Shishlina, N., V. Sevastyanov \& R.E.M. Hedges. 2012. Isotope ratio study of Bronze Age samples from the Eurasian Caspian steppes, in E. Kaiser, J. Burger \& W. Schier (ed.) Population dynamics in prehistory and early history: new approaches by using stable isotopes and genetics: 177-97. Berlin: De Gruyter.
SJögren, K.-G., T.D. Price \& K. Kristiansen. 2016. Diet and mobility in the Corded Ware of Central Europe. PLoS ONE 11: e0155083. https://doi:10.1371/journal.pone.0155083

Szmyt, M. 1999. Between west and east. People of the Globular Amphora Culture in Eastern Europe, 2950-2350 BC (Baltic-Pontic Studies 8). Poznań: Adam Mickiewicz University.

Vander Linden, M. 2016. Population history in third-millennium BC Europe: assessing the contribution of genetics. World Archaeology. Published online 3 August 2016.

https://doi.org/10.1080/00438243.2016.1209124

Received: 16 August 2016; Accepted: 3 January 2017; Revised: 3 January 2017 